\title{
DIDACTIC TESTING WITH SUPPORT OF VISUAL BASIC 6
}

\section{Jan LAVRINČÍK - Eva STRÁNSKÁ}

\begin{abstract}
The article deals with questions of didactic testing with support of Visual Basic 6 at lower secondary schools. It presents some issues of didactic tests' creation and explains which parts consist of didactic test software; the selection selection of programming language from compatibility and development point of view is emphasized. It acquaints the readers with hierarchy structure didactics test process. The article is supplemented with a flow diagram, and some examples of Visual Basic source codes.
\end{abstract}

Key words: didactics test, database, statistics, Visual Basic.

\section{DIDAKTICKÉ TESTOVÁNÍ POMOCÍ APLIKACE VISUAL BASIC 6}

Resumé: Článek se zabývá otázkou didaktického testování vaplikaci Visual Basic 6. Poukazuje na některé nezvyklosti v tvorbě didaktických testù. Vysvětluje z jakých částí se skládá didaktický testovací program, zdůrazňuje výběr programovacího jazyka z hlediska kompatibility, vývoje a budoucího rozšiření. Seznamuje čtenáre s hierarchickou strukturou didaktických testovacích procesů. Příspěvek je doplněn o vývojové diagramy a ukázky zdrojových kódů.

Klíčová slova: didaktický test, databáze, statistika, Visual Basic.

\section{1 Úvod}

Ověřování dosažených vědomostí a dovedností u žáků je nedílnou součástí edukačního procesu. Ke klasickým metodám zjištování vědomostí a dovedností žáků řadíme ústní a písemné zkoušení a využití didaktického testu.

Pedagogové si v poslední době více oblíbili písemné testování než ústní. V rámci jednoho písemného zkoušení si pedagog oveří úroveň znalostí a dovedností u všech žáků najednou. Žák není vystaven takovému stresu jako u ústního zkoušení, odpověd' si v klidu rozmyslí, popřr. opraví, doplní. Nevýhodou je ale opisování od souseda, z „taháku“ apod. Podobné aspekty mohou ovlivnit výsledky jednotlivých žáků. Jednou z možných obran pedagoga je rozdělení žáků na skupiny A, B; postrašení žáka okamžitým odebráním testu a ohodnocení testu špatným klasifikačním stupněm, apod.

V současné době se nabízí další možnost, jak testovat vědomosti žáků a vyhnout se nepř́ijemným aspektům jako u klasického zkoušení, a to použití elektronického didaktického testu (v př́spěvku zmíníme didaktické testování pomocí aplikace Visual Basic 6).

Proti nechtěnému úniku informací, opisování, můžeme zvolit (podobně jako u písemného zkoušení) horizontální diferenciaci na skupiny A, B. S nástupem moderních informačních a komunikačních technologií je nutné vylepšit (podobně jako v oblasti šifrovaní) algoritmy proti kopírování a úniku informací (srovnání DES $\rightarrow$ AES). Moderní mobilní telefony a komunikátory umožňují díky integrované kameře a komunikačním standardům Bluetooth IEEE 802.15.1, WiFi IEEE 802.11 (Wireless LAN) a nově WiMax (Worldwide Interoperability for Microwave Access) rychlý bezdrátový přenos dat libovolného typu. Spolu s použitím moderních komprimačních a šifrovacích nástrojů (např. šifrování AES, RC6 a komprimace LZMA, Bzip2, RAR) se stávají pomůckou v kladném, ale i záporném smyslu z pohledu didaktického testování.

Další oblastí, které věnujeme pozornost, je nemožnost později testy editovat a měnit jejich obsah. S ohledem na ekologické aspekty, jež jsou v dnešní době „velmi moderní“ (1), je užívání elektronického didaktickému systému k životnímu prostředí mnohem více šetrnější než klasické metody ověřování.

\section{Teorie didaktických testů}

Edukační proces můžeme chápat jako řízený proces, ve kterém zpravidla rozlišujeme dvě fáze: sdělování nových poznatkù a kontrolu množství a kvality osvojených poznatků (2). V př́ispěvku věnujeme pozornost fázi druhé.

Obecně v životě je hodnocení důležitou součástí lidské činnosti a může ovlivnit jednání 
člověka. Školní hodnocení má mnoho podob, klade vysoké nároky na osobnost pedagoga, na princip objektivity a týká se různých vztahů v systému školy. Nejčastěji však učitel hodnotí žáky. M. Pasch školní hodnocení definuje jako systematický proces, který vede k určení kvality a výkonů vykazovaných žákem nebo skupinou žáků (3).
Pro vytyčení pojmu didaktický test jsme zvolili definici P. Byčkovského: „Didaktický test je nástroj systematického zjištování výsledků výuky. Obecně může učitel volit mezi ústní zkouškou a testováním. V tabulce 1 uvádíme jednu z možných klasifikací testü“ (3).

\begin{tabular}{|c|c|c|c|c|}
\hline $\begin{array}{l}\text { KLASIFIKAČNÍ } \\
\text { HLEDISKO }\end{array}$ & \multicolumn{4}{|c|}{ DRUHY TESTU゚ } \\
\hline $\begin{array}{c}\text { Měřená charakteristika } \\
\text { výkonu }\end{array}$ & \multicolumn{2}{|c|}{ rychlosti } & \multicolumn{2}{|r|}{ úrovně } \\
\hline $\begin{array}{l}\text { Dokonalost přípravy } \\
\text { testu a jeho } \\
\text { příslušenství }\end{array}$ & \multicolumn{2}{|c|}{ standardizované } & \multicolumn{2}{|c|}{ nestandardizované } \\
\hline $\begin{array}{l}\text { Povaha činnosti } \\
\text { testovaného }\end{array}$ & \multicolumn{2}{|c|}{ kognitivní } & \multicolumn{2}{|c|}{ psychomotorické } \\
\hline $\begin{array}{l}\text { Míra specifičnosti } \\
\text { učení zjišstovaného } \\
\text { testem }\end{array}$ & \multicolumn{2}{|c|}{ výsledků výuky } & \multicolumn{2}{|c|}{ studijních předpokladů } \\
\hline Interpretace výkonu & \multicolumn{2}{|c|}{ rozšiřující (relativního výkonu) } & \multicolumn{2}{|c|}{ ověřující (absolutního výkonu) } \\
\hline $\begin{array}{l}\text { Časové zařazení do } \\
\text { výuky }\end{array}$ & vstupní & \multicolumn{2}{|c|}{ průběžné (formativní) } & výstupní (sumativní) \\
\hline Tematický rozsah & \multicolumn{2}{|c|}{ monotematické } & \multicolumn{2}{|c|}{ Polytematické } \\
\hline $\begin{array}{l}\text { Míra objektivity } \\
\text { skórování }\end{array}$ & $\begin{array}{l}\text { objektivně } \\
\text { skórovatelné }\end{array}$ & $\begin{array}{l}\text { kvaz } \\
\text { skó }\end{array}$ & $\begin{array}{l}\text { ktivně } \\
\text { elné }\end{array}$ & $\begin{array}{l}\text { subjektivně } \\
\text { skórovatelné }\end{array}$ \\
\hline
\end{tabular}

Tabulka 1: Druhy didaktických testů.

Didaktický test je určen výhradně k posuzování úrovně vědomostí a dovedností, které žák získal v průběhu výuky, nikoli k měření obecných rysů osobnosti studenta.

\section{Vyznačuje se podstatnými PEDAGOGICKÝMI} KRITÉRII (3):

- validita (platnost): test měří to, co má měřit (tzn. slouží svému účelu);

- reliabilita (spolehlivost): test je spolehlivý a přesný (tzn. při opětovném použití testu získáme tytéž výsledky);

- citlivost: test odpovídá svou náročností předpokládané úrovni vědomostí žákủ;

- objektivita: test splňuje přesná kritéria;

- použitelnost: existuje přesný návod na vyhodnocení testu.

Neméně důležitá jsou TECHNICKÁ KRITÉRIA PRO ELEKTRONICKÉ TESTOVÁNÍ (4), (5):

- bezpečnost: test není možno samovolně opustit, popř. restartovat;
- výběr prvků:možnost náhodného výběru otázek (bez opakování);

- zabezpečení: možnost šifrování databáze;

- kritéria klasifikace: nastavení kritérií klasifikace;

- tiskové výstupy: možnost tiskového výstupu testů;

- archivace výsledků: archivace výsledků k nahlédnutí a statistikám.

\section{Specifikace technického řešení} elektronického testování ve Visual Basic 6

Z hlediska tvorby elektronických testů $\mathrm{v}$ aplikaci Visual Basic lze $\mathrm{k}$ problematice testování přistoupit dvěma způsoby, jež se týkají datové struktury souborů $s$ testy. Testy můžeme jednoduše načítat z nechráněných (nešifrovaných) souborů textového typu předkládaných $\mathrm{v}$ ukázce č. 1 . 
Ukázka 1: Načítáni externího souboru textového typu.

Open (App.Path \& "\nazevsouboru.txt ") For Input \#1 'načtení externí databáze

...

Label1. Caption $=$ DATABAZE (intRandom)

'vyběr náhodné položky z obecné

databáze

Databázi lze také šifrovat a zvýšit tak bezpečnost nechtěného př́stupu $\mathrm{k}$ testovacím otázkám a správným odpovědím. Můžeme vybírat ze standardizovaných symetrických

šifrovacích algoritmů (DES, AES) nebo alternativních šifer (RC4, Twofish, MARS, RC6, apod.), (6, s. 103).

Ukázka 2: Vytvoření náhodného klíče pro algoritmus RC4.

ReDim PreKey (7+Rnd*6) 'vytvoření náhodné délky šifrovacího řetězce RC4 algoritmu

Ze struktury databáze je možné vyčíst informace o typu úlohy. $U$ úloh $s$ výběrem možností zjistíme počet nabízených možností. Jednotlivé otázky mohou být načítány dle ukázek uvedených v kapitole 4.

Výběr jednotlivých otázek je ovlivněn typem algoritmu. Obecně můžeme říci, že z hlediska praxe se jeví jako nejčastější volba použití standardních funkcí. Nejběžněji se setkáváme s funkcemi Mid\$ (výběr znaků zvoleného řetězce definované pozice), Trim\$ (odstranění prázdných znaků na začátku a konci řetězce) nebo Replace (Nahrazení definovaných znaků jinými znaky), (7), (8).

Ukázka 3: Ukázka výběru znaků z obecného řetězce.

$\mathrm{C}=$ Label1 'načtení obsahu Label1 do proměnné C

$C=\operatorname{Mid}(C, 1,40)$ 'Vyběr znaků od pozice 1 do pozice 40

$\mathrm{CQ}=\operatorname{Trim\$ }(\mathrm{C})$ 'Odstranění prázdných znaki̊ z vỷraného řetězce

Z vyučovaných předmětů nižšího sekundárního vzdělávání jsme si pro modelovou ukázku vybrali český jazyk - mluvnici. Na př́kladu ukážeme opakovací a doplňovací cvičení (doplňování měkkého $i$ a tvrdého $y$ ). Univerzální zpracování didaktického testu můžeme aplikovat také voblasti tvarosloví, skladby, slovní zásoby (doplňování měkkého $i$ a tvrdého $y$ ve slovech přejatých, cizího původu, ve shodě př́sudku s podmětem, v koncovkách podstatných nebo př́idavných jmen apod.)

Ukázka 4: Ukázka načítání prvků z databáze.

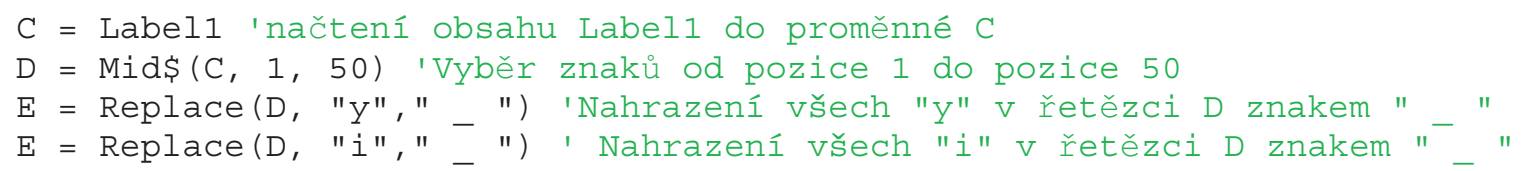

Pracujeme-li s předponami o pevné délce řetězce můžeme použít i syntax s funkcí Left (resp. Right). Funkce Left a Right nám umožní výběr části řetězce o pevné délce $z$ levé nebo pravé strany řetězce (např. vikýř $\rightarrow$ kýŕ, resp. sokolí (let) $\rightarrow$ sokol_(let)). Z prríkladu je zřejmé, že můžeme ovlivnit i délku řezce, v prvním př́padě byly dva znaky a $\mathrm{v}$ druhém pouze jeden znak.
Pro vyhodnocení použijeme jednoduchou statistiku, která počítá za správně a chybně zodpovězené odpovědi procentuální úspěšnost. Aritmetický průměr je nejčastěji používaný nástroj pro jednoduché statistické vyhodnocování dat (9) a velmi často si jej pedagogové volí jako kritérium rozdělení známek. 
Ukázka 5: Ukázka načitání prvků z databáze (10).

$\mathrm{cc}=(\mathrm{aa} /(\mathrm{aa}+\mathrm{bb}+0.000000001)) * 100$ 'rovnice pro výpočet aritmetického průměru se zajištěním nenulové hodnoty dělitele

Label19 = cc 'načtení proměnné cc do Label19

Label19 = CInt(Label19) ' zaokrouhlení výsledku na celé číslo

Zdrojové kódy testovacího programu jsou obsáhlejší než př́klady uvedené výše. Tvoří je řada modulů, jejichž strukturu primárně

určenou pro vzdělávání se pokusíme naznačit na vývojovém diagramu 1.

Vývojový diagram 1: Struktura testovací aplikace.

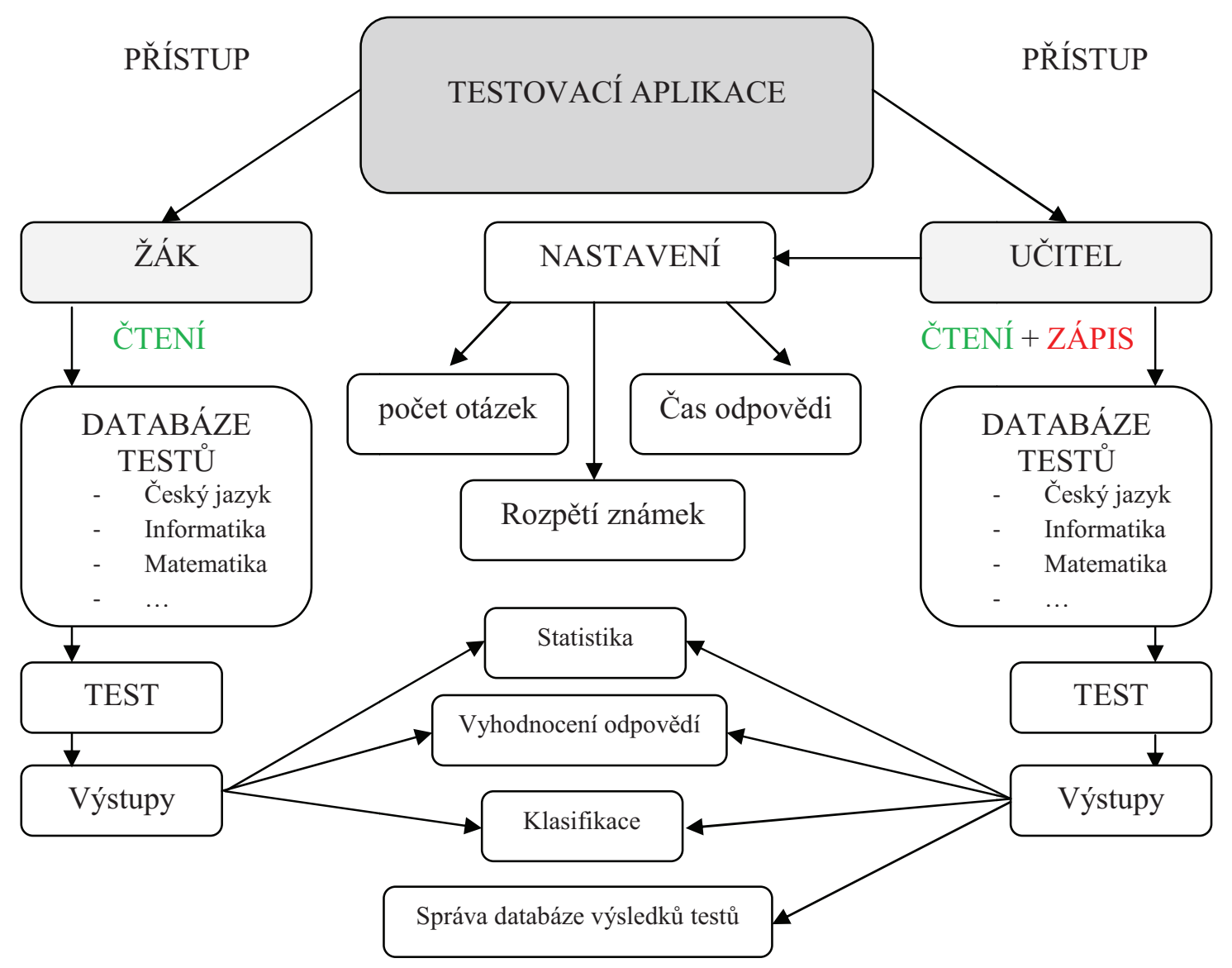

\section{Závěr}

V předloženém př́spěvku jsme zmínili vytváření a užívání elektronických testovacích systémů, definovali jsme standardy jejich tvorby a možnosti využití elektronických didaktických testů v edukačního procesu.

Domníváme se, že zařazení elektronických testů do edukačního procesu může významně ovlivnit rozvoj strategického uvažování a rozhodovacích schopností jedince. Jejich užívání usnadní pedagogům testování vědomostí žáků, získají okamžitou zpětnou vazbu, ušetř́ čas (např. na aktivizační a alternativní metody ve výuce) apod.
Využití elektronických testovacích systémů ocení především absolventi vysoké školy studijních kombinací s technickou a informační výchovou, ale není to podmínkou. Pedagogové získají pro žáky nový, zajímavý a velmi efektivní způsob elektronického testování.

Možnost dalšího vývoje elektronického testování je neustále velmi aktuální.

\section{Literatura}

[1] LAVRINČÍK, J., KLEMENT, M. Tvorba autorských instalerů pomocí aplikace Visual Basic 6. In Strategie technického vzdělávání v reflexi doby. 1. vyd. Ústí nad Labem : Fakulta výrobních technologií 
a managementu, 2009. ISBN 80-7414-1263.

[2] DOSTÁL, J. Školní informační systémy. In Infotech 2007 - moderni informačni technologie ve vzdělávání. Olomouc : Votobia, 2007. s. 540 - 546. ISBN 978-807220-308-6. Dostupné na www: $<$ http://infotech.upol.cz $>$.

[3] CHRÁSKA, M. Didaktické testy : přiručka pro učitele a studenty učitelství. 1. vyd. Brno : Paido, 1999. 91 s. ISBN 80-85-93168-0.

[4] STOFFOVÁ, V. Didaktické aspekty kontroly úrovne vedomosti pomocou počítača. In: MEDACTA 91. č. 3. Nitra, Pedagogická fakulta, 1991, s. 153-161.

[5] STOFFOVÁ, V. Automation of programmer's knowledge testing. In: Acta Mathematica \& Informatica 1. Nitra : Vysoká škola pedagogická, 1992. S. $79-$ 97.

[6] LAVRINČÍK, J. Executables Compression Algorithms Comparison. In Didmattech 2008. 1. vyd. Eger : Eszterházy Károly College, 2008, s. 103 - 106. ISBN 978-9639894-17-4.

[7] KLEMENT, M. Základy programováni vjazyce Visual Basic. 1. vyd. Olomouc : VUP, 2002. 336 s. ISBN 80-244-0472-9.

[8] LAVRINČÍK, J. Terminologický slovník programování ve Visual Basic 6. Journal of Technology and Information Education,
2009, Olomouc - EU, Palacký Univerzity, Volume 1, Issue 1, p. 119 - 122. ISSN 1803-537X.

[9] CHRÁSKA, M. Metody pedagogického výzkumu. 1. vyd. Olomouc : VUP, 2007. 265 s. ISBN 978-80-247-1369-4.

[10] LAVRINČÍK, J., KLEMENT, M. Potenciální možnosti využití programovacího jazyka Visual Basic 6 v hodinách českého jazyka a literatury. In Tradiční a netradiční metody a formy práce $v$ hodinách českého jazyka. v tisku.

Mgr. Jan Lavrinčík, DiS.

Katedra technické a informační výchovy

Pedagogická fakulta UP

Žižkovo nám. č. 5

771 40, Olomouc, ČR

Tel: +420 585635813

E-mail: nobilis.felis@seznam.cz

Www pracoviště: www.kteiv.upol.cz

Mgr. Eva Stránská

Katedra českého jazyka a literatury

Pedagogická fakulta UP

Žižkovo nám. č. 5

771 40, Olomouc, ČR

Tel: +420 585635655

E-mail: EStranska@seznam.cz

Www pracoviště : http://kcjl.upol.cz 